\title{
Unravelling the Antiproliferative Activity of 1,2,5-oxadiazole Derivatives
}

\author{
DANIEL EHRSAM ${ }^{1 *}$, FABIOLA PORTA $^{1 *}$, MATTEO MORI $^{2}$, HENRIETTE E. MEYER ZU SCHWABEDISSEN $^{1}$, \\ LISA DALLA VIA ${ }^{3}$, AİDA NELLY GARCIA-ARGAEZ ${ }^{3}$, LIVIA BASILE ${ }^{4}$, \\ FIORELLA MENEGHETTI ${ }^{2}$, STEFANIA VILLA ${ }^{2}$ and ARIANNA GELAIN ${ }^{2}$ \\ ${ }^{1}$ Biopharmacy, Department of Pharmaceutical Sciences, University of Basel, Basel, Switzerland; \\ ${ }^{2}$ Department of Pharmaceutical Sciences, University of Milan, Milan, Italy; \\ ${ }^{3}$ Department of Pharmaceutical and Pharmacological Sciences, University of Padua, Padua, Italy; \\ ${ }^{4}$ Department of Drug Sciences, Section of Medicinal Chemistry, University of Catania, Catania, Italy
}

\begin{abstract}
Aim: To develop several new derivatives aimed to complete the studies concerning the antiproliferative profile of the oxadiazole derivative MD77. Materials and Methods: The substitution pattern around the phenyl rings of this compound was analyzed through the synthesis of positional isomers and of analogues bearing different substituents at the para positions (2-12). Results: The results of the antiproliferative activity of these derivatives versus HCT-116 and HeLa cancer cell lines shed light on the effects of the presence, nature and position of such substituents. Notably, derivative 4, a regioisomer of $\mathbf{1}$ in which the substituents at the para positions of the phenyl rings were inverted, showed the best antiproliferative profile, exhibiting a significant activity also against MCF7 and MDAMB 468 cancer cell lines. Conclusion: Preliminary results showed the ability of compound 4 to reduce the viability of cancer cells by counteracting human recombinant topoisomerase II a relaxation activity.
\end{abstract}

Cancer still ranks second behind cardiovascular diseases among the leading causes of death globally (1) and chemotherapy is the mainstay in the reduction of mortality. Nevertheless, anticancer drugs are generally extremely toxic, while their poor selectivity and insurgence of resistance mechanisms clearly underscore the need of developing novel chemical entities, exhibiting higher efficacy and minor side-effects.

\footnotetext{
*These Authors contributed equally to this study.

Correspondence to: Stefania Villa, Department of Pharmaceutical Sciences, University of Milan, via L. Mangiagalli 25, 20133 Milan, Italy. Tel: +39 0250319368, Fax: +39 0250319359, e-mail: stefania.villa@unimi.it
}

Key Words: Furazane, cytotoxicity, topoisomerase II, HCT-116, HeLa, MCF-7, MDA-MB 468.
During our ongoing research concerning the identification of new compounds endowed with anticancer activity (2-11), we investigated the properties of 1,2,5-oxadiazole derivatives. Among them, MD77 ( $N$-[4-(4-chloro-phenyl)1,2,5-oxadiazol-3-yl]-4-trifluoromethyl-benzamide 1) (Figure 1) showed a good antiproliferative activity profile against a panel of 58 tumor cell lines derived from 9 cancer cell types $\left(\mathrm{GI}_{50}\right.$ values ranging from $6.75 \times 10^{-6} \mathrm{M}$ against renal cancer cell TK10, to $5.46 \times 10^{-7} \mathrm{M}$, leukemia, HL60TB), and showed Tumor Growth Inhibition (TGI) values lower than $1.00 \times 10^{-4} \mathrm{M}$ in most cancer cell lines (3). Therefore, with the aim to integrate the previously obtained data (2), we decided to investigate the effects of phenyl ring substitutions on the antiproliferative activity, by designing (Figure 1) and synthesizing (Figure 2) several compounds related to 1 (212), to complete our library (2). Some compounds showed on the phenyl rings the same substituents of $\mathbf{1}$ but at different positions, while others were substituted with a trifluoromethyl group or with a chlorine atom.

All compounds were tested against HCT116 and HeLa cell lines. Since isomer 4 showed the most interesting growth inhibition results, we also explored its effect on the cellular viability of breast cancer cells (MCF-7 and MDA-MB 468), and the outcomes confirmed the encouraging trend of activity. We also investigated its mechanism of action using as probes its derivative $\mathbf{2 0}$ (Figure 3), bearing fluorescent moieties, and observing their behavior into the cells. Finally, preliminary studies were performed to explore its potential molecular targets.

\section{Materials and Methods}

Chemistry. Reagents and solvents were all purchased from SigmaAldrich (Saint Louis, MO, USA), except for Oregon Green 488 carboxylic acid succinimide ester, obtained from Thermo Fisher Scientific (Waltham, MA, USA), and were used without further purification. Anhydrous solvents were used without further drying. 
Reactions, performed in conventional conditions or by a microwave synthesizer (Biotage ${ }^{\circledR}$ Initiator; Biotage, Upsala, Sweden), were monitored by thin-layer chromatography on aluminum-backed Silica Gel 60 plates (70-230 mesh; Merck, Darmstadt, Germany), using an ultraviolet fluorescent lamp at $254 \mathrm{~nm}$ and $365 \mathrm{~nm}$. Visualization was supported by opportune staining reagents. Purification of intermediates and final compounds was performed via flash column chromatography on Geduran Si 60 (40-63 $\mu \mathrm{m}$, Merck). All the tested compounds were characterized by means of ${ }^{1} \mathrm{H}$ and ${ }^{13} \mathrm{C}$ NMR spectra on a Varian Oxford $300 \mathrm{MHz}$ instrument (Palo Alto, CA, USA), equipped with a non-reverse probe at $25^{\circ} \mathrm{C}$, operating at 300 $\mathrm{MHz}$ for ${ }^{1} \mathrm{H}, 75 \mathrm{MHz}$ for ${ }^{13} \mathrm{C}$ and $282 \mathrm{MHz}$ for ${ }^{19} \mathrm{~F}$. Chemical shifts are expressed as $\delta(\mathrm{ppm})$ from tetramethylsilane resonance in the indicated solvent (TMS: $\delta=0.0 \mathrm{ppm})$. The coupling constants $(J$ values) are expressed in Hertz $(\mathrm{Hz})$. All spectroscopic data match the assigned structures. Melting points were determined in open capillary tubes on a Buchi Melting Point B-540 (Buchi, Flawil, Switzerland). Mass spectrometry analyses were carried out on an LTQ Orbitrap XL mass spectrometer (Thermo Fisher Scientific) equipped with a Finnigan IonMax Electrospray interface. The purity of the compounds was checked by HPLC analysis $(\geq 95 \%)$.

The synthesis of 4-bromo and 4-methyl benzoyl chlorides was performed following the procedure reported in literature (2).

Synthesis of 1,2,5-oxadiazol-3-amines 17a-g. The amines 17a-g were obtained as previously described (Figure 2) (3). The characterization of the new key intermediates $\mathbf{1 7 b}$ and $\mathbf{1 7 f}$ is reported below.

4-(4-methylphenyl)-1,2,5-oxadiazol-3-amine (17b). Starting compound: 4-methylbenzaldehyde $(1.2 \mathrm{mmol})$. Yield: $8 \%$ as white solid (m.p.: $\left.126.7-128.5^{\circ} \mathrm{C}\right) .{ }^{1} \mathrm{H}-\mathrm{NMR}\left(\mathrm{CDCl}_{3}\right)$ : $\delta 2.38\left(\mathrm{~s}, 3 \mathrm{H}, \mathrm{CH}_{3}\right)$, 4.26 (br s, $2 \mathrm{H}, \mathrm{NH}_{2}$ exchanged with $\left.\mathrm{D}_{2} \mathrm{O}\right), 7.36(\mathrm{~d}, J=8.2 \mathrm{~Hz}, 2 \mathrm{H}$, $\mathrm{ArH}), 7.64(\mathrm{~d}, J=8.2 \mathrm{~Hz}, 2 \mathrm{H}, \mathrm{ArH}) \mathrm{ppm} .{ }^{13} \mathrm{C}-\mathrm{NMR}\left(\mathrm{CDCl}_{3}\right): \delta$ $21.44,122.58,127.44,130.09,140.87,146.92,154.31$ ppm. ESIMS: calcd. for $\mathrm{C}_{9} \mathrm{H}_{9} \mathrm{~N}_{3} \mathrm{O} 175$, found $176[\mathrm{M}+\mathrm{H}]^{+}$.

4-(4-bromophenyl)-1,2,5-oxadiazol-3-amine (17f). Starting compound: 4-bromobenzaldehyde $(2.70 \mathrm{mmol})$. Yield: $18 \%$ as light brown solid (m.p.: $\left.143.8-144.8^{\circ} \mathrm{C}\right) .{ }^{1} \mathrm{H}-\mathrm{NMR}\left(\mathrm{CDCl}_{3}\right): \delta 4.20$ (br s, $2 \mathrm{H}, \mathrm{NH}_{2}$ exchanged with $\left.\mathrm{D}_{2} \mathrm{O}\right), 7.62(\mathrm{~d}, J=8.3 \mathrm{~Hz}, 2 \mathrm{H}, \mathrm{ArH}), 7.68$ $(\mathrm{d}, J=8.3 \mathrm{~Hz}, 2 \mathrm{H}, \mathrm{ArH}) \mathrm{ppm} .{ }^{13} \mathrm{C}-\mathrm{NMR}\left(\mathrm{CDCl}_{3}\right): \delta 125.02,125.89$, $129.38,135.68,146.70,154.56 \mathrm{ppm}$. ESI-MS: calcd. for $\mathrm{C}_{8} \mathrm{H}_{6} \mathrm{BrN}_{3} \mathrm{O} 240$, found $241[\mathrm{M}+\mathrm{H}]^{+}$.

Synthesis of 1,2,5-oxadiazol-3-amides 1-12 and 18. Compounds 14, 7-9 and 12 were obtained as previously reported (2), while the new derivatives $5,6,10,11$ and 18 were synthesized using the following procedures.

Synthesis of 4-bromo-N-(4-(4-chlorophenyl)-1,2,5-oxadiazol-3yl)benzamide (5). 4-Bromobenzoyl chloride (0.306 $\mathrm{mmol})$ was added to a solution of $17 \mathrm{c}(0.255 \mathrm{mmol})$ and $4-$ dimethylaminopyridine $(0.306 \mathrm{mmol})$ in dry 1,2 -dichloroethane $(1.5 \mathrm{ml})$, at room temperature, under nitrogen atmosphere. The reaction mixture was irradiated in a microwave synthesizer at $120^{\circ} \mathrm{C}$ and $300 \mathrm{~W}$ for $45 \mathrm{~min}$. The solution was treated with water $(1.5 \mathrm{ml})$ and extracted with dichloromethane $(3 \times 1 \mathrm{ml})$. The collected organic phases were washed with $1 \mathrm{~N} \mathrm{HCl}$, dried over $\mathrm{Na}_{2} \mathrm{SO}_{4}$, filtered and evaporated under reduced pressure to give

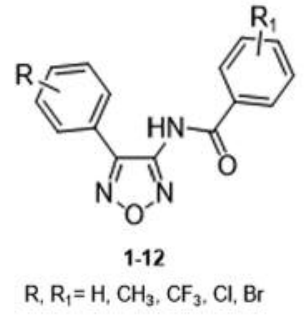

\begin{tabular}{cccccc}
\hline Compound & $\mathbf{R}$ & $\mathbf{R}_{\mathbf{1}}$ & Compound & $\mathbf{R}$ & $\mathbf{R}_{\mathbf{1}}$ \\
\hline $\mathbf{1}$ & $p-\mathrm{Cl}$ & $p-\mathrm{CF}_{3}$ & 7 & $p-\mathrm{Cl}$ & $\mathrm{H}$ \\
$\mathbf{2}$ & $p-\mathrm{Cl}$ & $m-\mathrm{CF}_{3}$ & $\mathbf{8}$ & $m-\mathrm{Cl}$ & $p-\mathrm{CF}_{3}$ \\
$\mathbf{3}$ & $p-\mathrm{Cl}$ & $0-\mathrm{CF}_{3}$ & 9 & $0-\mathrm{Cl}$ & $p-\mathrm{CF}_{3}$ \\
4 & $p-\mathrm{CF}$ & $p-\mathrm{Cl}$ & 10 & $p-\mathrm{Br}$ & $p-\mathrm{CF}_{3}$ \\
$\mathbf{5}$ & $p-\mathrm{Cl}$ & $p-\mathrm{Br}$ & 11 & $p-\mathrm{CH}_{3}$ & $p-\mathrm{CF}_{3}$ \\
$\mathbf{6}$ & $p-\mathrm{Cl}$ & $p-\mathrm{CH}_{3}$ & 12 & $\mathrm{H}$ & $p-\mathrm{CF}_{3}$ \\
\hline
\end{tabular}

Figure 1. The antiproliferative properties of twelve 1,2,5-oxadiazole derivatives were investigated.

a residue, which was purified by flash column chromatography (eluent mixture: cyclohexane/ethyl acetate, 80:20).

Yield: $11 \%$ as brown solid (m.p.: $\left.195.5-197.0^{\circ} \mathrm{C}\right) .{ }^{1} \mathrm{H}-\mathrm{NMR}$ $\left(\mathrm{CDCl}_{3}\right): \delta 7.47(\mathrm{~d}, J=8.1 \mathrm{~Hz}, 2 \mathrm{H}, \mathrm{ArH}), 7.65(\mathrm{~d}, J=8.7 \mathrm{~Hz}, 2 \mathrm{H}$, ArH), 7.68 (d, J=8.7 Hz, 2H, ArH), 7.76 (d, J=8.1 Hz, 2H, ArH), 8.18 (br s, $1 \mathrm{H}, \mathrm{NH}$ exchanged with $\left.\mathrm{D}_{2} \mathrm{O}\right)$ ppm. ${ }^{13} \mathrm{C}-\mathrm{NMR}\left(\mathrm{CDCl}_{3}\right)$ : ठ $123.78,127.46,129.16,129.25,129.56,131.80,133.18,135.03$, 147.18, 153.76, 166.48 ppm. ESI-MS: calcd. for $\mathrm{C}_{15} \mathrm{H}_{9} \mathrm{BrClN}_{3} \mathrm{O}_{2}$ 378 , found $377[\mathrm{M}-\mathrm{H}]^{-}$.

General procedure for the synthesis of amides 6, 10, 11 and 18. To a suspension of $\mathrm{NaH} 60 \%$ dispersion in mineral oil $(0.3 \mathrm{mmol})$ in dry $\mathrm{N}$ - $\mathrm{N}$-dimethylformamide $(3 \mathrm{ml})$ cooled on an ice bath under nitrogen atmosphere, the appropriate 4-substuituted phenyl-1,2,5oxadiazol-3-amine $(0.25 \mathrm{mmol})$ was added, and the mixture was stirred at $0^{\circ} \mathrm{C}$ for $20 \mathrm{~min}$. Subsequently, the suitable acyl chloride $(0.3 \mathrm{mmol})$ was added dropwise at $0^{\circ} \mathrm{C}$ and the mixture was stirred at $60^{\circ} \mathrm{C}$ for $12 \mathrm{~h}$. After the addition of water $(3 \mathrm{ml}), N-N$ dimethylformamide was removed under reduced pressure and the obtained residue was extracted with ethyl acetate $(3 \times 2 \mathrm{ml})$. The organic phase was dried over $\mathrm{Na}_{2} \mathrm{SO}_{4}$ and evaporated under vacuum to obtain the crude product, which was purified by flash column chromatography (eluent mixture: cyclohexane/ethyl acetate, 80:20).

4-methyl-N-(4-(4-chlorophenyl)-1,2,5-oxadiazol-3-yl)benzamide (6). Starting compounds: 17c and 4-methylbenzoyl chloride. Yield: $24 \%$ as brown solid (m.p.: 163.5-164.0 $\left.{ }^{\circ} \mathrm{C}\right) .{ }^{1} \mathrm{H}-\mathrm{NMR}\left(\mathrm{CDCl}_{3}\right)$ : $\delta 2.37(\mathrm{~s}$, $3 \mathrm{H}, \mathrm{CH} 3), 7.25$ (d, $J=8.4 \mathrm{~Hz}, 2 \mathrm{H}, \mathrm{ArH}), 7.38(\mathrm{~d}, J=8.4 \mathrm{~Hz}, 2 \mathrm{H}$, ArH), 7.58 (d, $J=8.6 \mathrm{~Hz}, 2 \mathrm{H}, \mathrm{ArH}), 7.70$ (d, $J=8.6 \mathrm{~Hz}, 2 \mathrm{H}, \mathrm{ArH})$, 8.07 (br s, $1 \mathrm{H}, \mathrm{NH}$ exchanged with $\left.\mathrm{D}_{2} \mathrm{O}\right) \mathrm{ppm} .{ }^{13} \mathrm{C}-\mathrm{NMR}\left(\mathrm{CDCl}_{3}\right)$ : o $21.91,124.31,127.89,129.06,129.17,129.79,130.06,137.27$, $144.59,149.13,149.75,165.50 \mathrm{ppm}$. ESI-MS: calcd. for $\mathrm{C}_{16} \mathrm{H}_{12} \mathrm{ClN}_{3} \mathrm{O}_{2} 313$, found $312[\mathrm{M}-\mathrm{H}]^{-}$. 


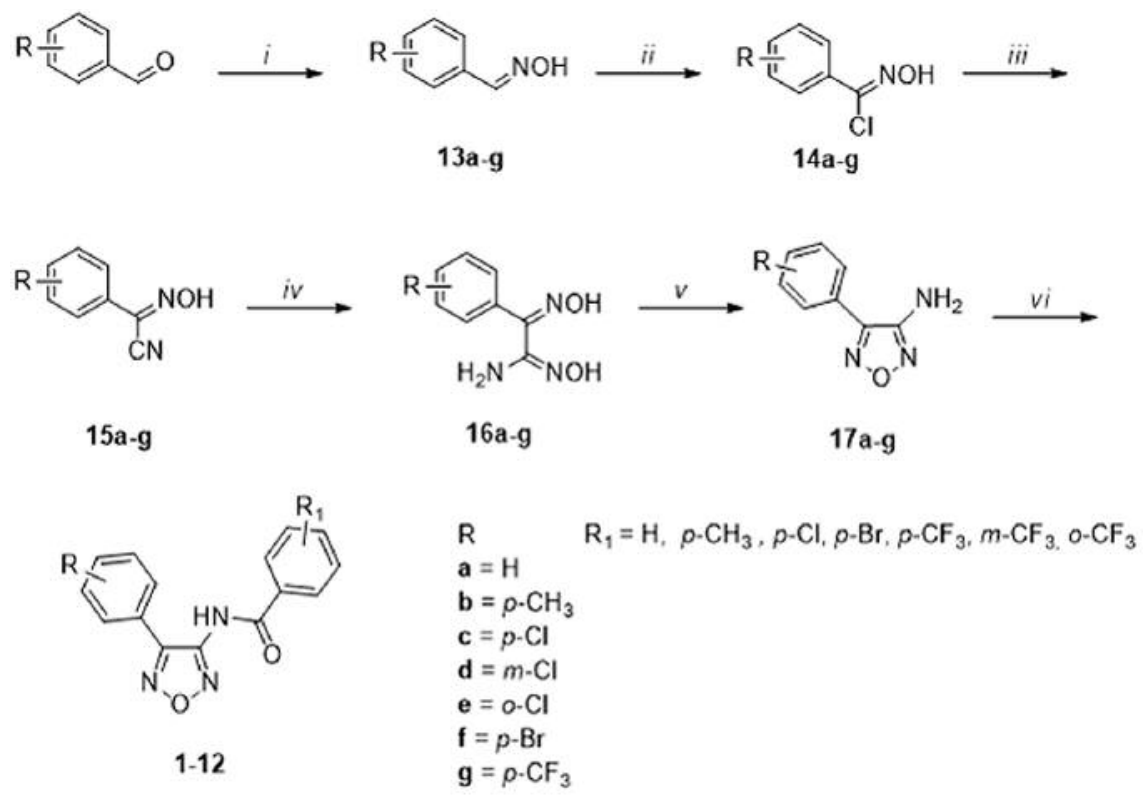

\begin{abstract}
Reagents and conditions: (i) $\mathrm{NH}_{2} \mathrm{OH} \mathrm{HCl}, \mathrm{NaHCO}_{3}$, methanol, reflux, $2 \mathrm{~h}_{\text {; }}$ (ii) $\mathrm{NCS}, \mathrm{N}$; $\mathrm{N}$ dimethylformamide, $\mathrm{rt}, 12 \mathrm{~h}$; (iii) $\mathrm{KCN}$, diethyl ether $/ \mathrm{H}_{2} \mathrm{O}, \mathrm{rt}, 5 \mathrm{~h}$; (iv) $\mathrm{NH}_{2} \mathrm{OH} \mathrm{HCl}$, $\mathrm{NaHCO}_{3}$, methanol, reflux, $12 \mathrm{~h}$; (v) $2 \mathrm{~N} \mathrm{NaOH}$, reflux, $12 \mathrm{~h}$; (vi) for 5: 4bromobenzylchloride, 4-dimethylaminopyridine, 1,2-dichloroethane, $\mathrm{mw}, 120^{\circ} \mathrm{C}, 45 \mathrm{~min}$; for 6,10 and $11: \mathrm{R}_{1} \mathrm{COCl}, 60 \% \mathrm{NaH}$, dry $\mathrm{N}, \mathrm{N}$-dimethylformamide, $\mathrm{N}_{2}, 60^{\circ} \mathrm{C}, 12 \mathrm{~h}$.
\end{abstract}

Figure 2. Several compounds related to 1 were synthesized.

4-trifluoromethyl-N-(4-(4-bromophenyl)-1,2,5-oxadiazol-3-yl)benzamide (10). Starting compounds: 17f and 4-trifluoro-methylbenzoyl chloride. Yield: $20 \%$ as off-white solid (m.p.: $\left.242.5-244.8^{\circ} \mathrm{C}\right) .{ }^{1} \mathrm{H}-\mathrm{NMR}$ $\left(\mathrm{CDCl}_{3}\right): \delta 7.57(\mathrm{~d}, J=8.7 \mathrm{~Hz}, 2 \mathrm{H}, \mathrm{ArH}), 7.64(\mathrm{~d}, J=8.7 \mathrm{~Hz}, 2 \mathrm{H}, \mathrm{ArH})$, 7.81 (d, $J=8.2 \mathrm{~Hz}, 2 \mathrm{H}, \mathrm{ArH}), 8.00$ (d, $J=8.2 \mathrm{~Hz}, 2 \mathrm{H}, \mathrm{ArH}), 8.15$ (br s, $1 \mathrm{H}, \mathrm{NH}$ exchanged with $\left.\mathrm{D}_{2} \mathrm{O}\right) \mathrm{ppm} .{ }^{13} \mathrm{C}-\mathrm{NMR}\left(\mathrm{CDCl}_{3}\right): \delta 121.50$, $122.76,125.12,126.33,129.22,129.25,133.18,135.19,135.42$, 135.63, 151.41, 170.08 ppm. ${ }^{19} \mathrm{~F}-\mathrm{NMR}\left(\mathrm{CD}_{3} \mathrm{OD}\right): \delta-63.63\left(\mathrm{~s}, \mathrm{CF}_{3}\right)$ ppm. ESI-MS: calcd. for $\mathrm{C}_{16} \mathrm{H}_{9} \mathrm{BrF}_{3} \mathrm{~N}_{3} \mathrm{O}_{2} 412$, found 411 [M-H] ${ }^{-}$.

4-trifluoromethyl-N-(4-(4-methylphenyl)-1,2,5-oxadiazol-3yl)benzamide (11). Starting compounds: $\mathbf{1 7 b}$ and 4trifluoromethylbenzoyl chloride. Yield: $19 \%$ as gray solid (m.p.: 118.8$\left.121.5^{\circ} \mathrm{C}\right) .{ }^{1} \mathrm{H}-\mathrm{NMR}\left(\mathrm{CDCl}_{3}\right): \delta 2.44\left(\mathrm{~s}, 3 \mathrm{H}, \mathrm{CH}_{3}\right), 7.36(\mathrm{~d}, J=8.2 \mathrm{~Hz}$, $2 \mathrm{H}, \mathrm{ArH}), 7.57$ (d, J=8.2 Hz, 2H, ArH), 7.79 (d, J=8.6 Hz, 2H, ArH), $7.98(\mathrm{~d}, J=8.6 \mathrm{~Hz}, 2 \mathrm{H}, \mathrm{ArH}), 8.12\left(\mathrm{br} \mathrm{s}, 1 \mathrm{H}, \mathrm{NH}\right.$ exchanged with $\mathrm{D}_{2} \mathrm{O}$ ) ppm. ${ }^{13} \mathrm{C}-\mathrm{NMR}\left(\mathrm{CDCl}_{3}\right): \delta 31.15,122.31,125.69,125.78,126.45$ (q), $126.25,127.69,127.89,128.32,130.29,130.45,134.31,141.66$, 148.57, 150.20, 165.78 ppm. ${ }^{19} \mathrm{~F}-\mathrm{NMR}\left(\mathrm{CD}_{3} \mathrm{OD}\right): \delta-63.75$ (s, CF3) ppm. ESI-MS: calcd. for $\mathrm{C}_{17} \mathrm{H}_{12} \mathrm{~F}_{3} \mathrm{~N}_{3} \mathrm{O}_{2} 347$, found 346 [M-H] ${ }^{-}$.

4-chloro-2-nitro- $N$-(4-(4-(trifluoromethyl)phenyl)-1,2,5-oxadiazol3-yl)benzamide (18). Starting compounds: $\mathbf{1 7 g}$ and 4-chloro-2nitrobenzoyl chloride. Yield: $52 \%$ as yellowish solid (m.p.: 208$\left.209^{\circ} \mathrm{C}\right) .{ }^{1} \mathrm{H}-\mathrm{NMR}\left(\mathrm{CD}_{3} \mathrm{OD}\right): \delta 7.77(\mathrm{~d}, J=8.2 \mathrm{~Hz}, 1 \mathrm{H}, \mathrm{ArH}), 7.86$ $(\mathrm{d}, J=5.3 \mathrm{~Hz}, 2 \mathrm{H}, \mathrm{ArH}), 7.90(\mathrm{~d}, J=2.0 \mathrm{~Hz}, 1 \mathrm{H}, \mathrm{ArH}), 8.00(\mathrm{~d}$,
$J=8.4 \mathrm{~Hz}, 2 \mathrm{H}, \mathrm{ArH}), 8.22(\mathrm{~d}, J=2.0 \mathrm{~Hz}, 1 \mathrm{H}, \mathrm{ArH}) \mathrm{ppm} .{ }^{13} \mathrm{C}-\mathrm{NMR}$ $\left(\mathrm{CD}_{3} \mathrm{OD}\right): \delta$ 118.60-122.18-125.67-129.40 (q), 123.02, 125.96126.02-126.08-126.16 (q), 127.59, 129.98, 130.42, 130.99, 131.54, 132.78-133.21-133.67-134.05 (q), 133.52, 146.98, 147.37, 153.30, $165.07 \mathrm{ppm} .{ }^{19} \mathrm{~F}-\mathrm{NMR}\left(\mathrm{CD}_{3} \mathrm{OD}\right)$ : $-63.04 \mathrm{ppm}$. ESI-MS: calcd. for $\mathrm{C}_{16} \mathrm{H}_{8} \mathrm{ClF}_{3} \mathrm{~N}_{4} \mathrm{O}_{4} 412$, found $411[\mathrm{M}-\mathrm{H}]^{-}$.

Synthesis of 2-amino-4-chloro- $N$-(4-(4-(trifluoromethyl)phenyl)1,2,5-oxadiazol-3-yl)benzamide (19). To a solution of benzamide 18 $(0.242 \mathrm{mmol})$ in ethyl acetate $(15.61 \mathrm{ml}), \mathrm{SnCl}_{2}(1.212 \mathrm{mmol})$ was added and the mixture was refluxed for $3 \mathrm{~h}$. A saturated aqueous solution of $\mathrm{NaHCO}_{3}$ was added until $\mathrm{pH}$ 7-8 and the precipitated tin salts were filtered. The aqueous phase was extracted with ethyl acetate $(3 \times 3 \mathrm{ml})$. The collected organic layers were dried over $\mathrm{Na}_{2} \mathrm{SO}_{4}$, filtered and evaporated under vacuum. The obtained residue was purified by flash column chromatography (eluent mixture: cyclohexane/ethyl acetate, 8:2) to afford intermediate 19.

Yield: $79 \%$ as white solid (m.p.: $\left.155-156^{\circ} \mathrm{C}\right) .{ }^{1} \mathrm{H}-\mathrm{NMR}\left(\mathrm{CD}_{3} \mathrm{OD}\right)$ :

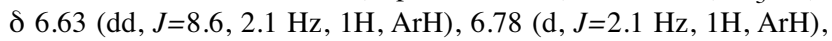
7.71 (d, $J=8.6 \mathrm{~Hz}, 1 \mathrm{H}, \mathrm{ArH}), 7.79$ (d, $J=8.4 \mathrm{~Hz}, 1 \mathrm{H}, \mathrm{ArH}), 7.94$ (d, $J=8.4 \mathrm{~Hz}, 1 \mathrm{H}, \mathrm{ArH}) \mathrm{ppm} .{ }^{13} \mathrm{C}-\mathrm{NMR}\left(\mathrm{CD}_{3} \mathrm{OD}\right): \delta 115.02,115.49$, $117.50,118.57-122.16-125.70-129.30$ (q), 125.96-126.04-126.11126.16 (q), $127.60,130.01,130.47,132.78-133.24-133.68-134.10$ (q), 138.07, $146.40,150.25,153.31,165.59$ ppm. ${ }^{19} \mathrm{~F}-\mathrm{NMR}$ $\left(\mathrm{CD}_{3} \mathrm{OD}\right): \delta-63.07$ ppm. ESI-MS: calcd. for $\mathrm{C}_{16} \mathrm{H}_{10} \mathrm{ClF}_{3} \mathrm{~N}_{4} \mathrm{O}_{2} 382$, found $383[\mathrm{M}+\mathrm{H}]^{+}$. 


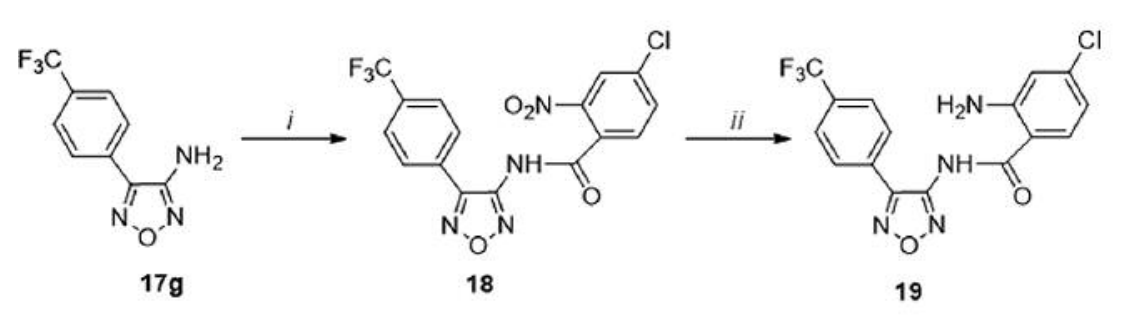

Reagents and conditions: $(i)$ a. $60 \% \mathrm{NaH}$, dry $\mathrm{N}, \mathrm{N}$-dimethylformamide, $\mathrm{N}_{2}, 0^{\circ} \mathrm{C}, 30$ min.; b. 4-chloro-2-nitrobenzoyl chloride, $60^{\circ} \mathrm{C}, 12 \mathrm{~h}$; (ii) $\mathrm{SnCl}_{2}$, ethylacetate, reflux, $3 \mathrm{~h}$; (jii) $5(6)$ carboxyfluoresceine, $N, N$-diisopropylethylamine, dry $N, N$-dimethylformamide, $\mathrm{N}_{2}, \mathrm{r}$.t., $5 \mathrm{~h}$.

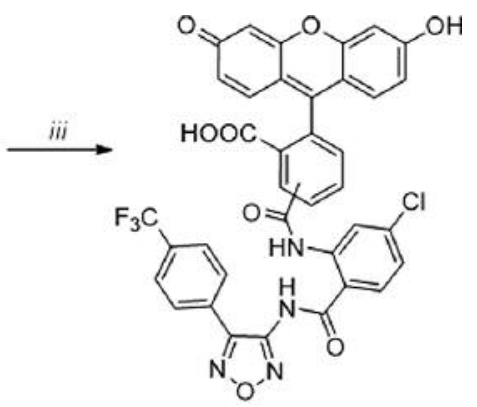

20

Figure 3. Derivative 20, bearing fluorescent moieties, was used as a probe.

Synthesis of $\mathrm{N}$-\{5-chloro-2-[4-(4-trifluoromethyl-phenyl)-1,2,5oxadiazol-3-ylcarbamoyl]-phenyl\}-2-(6-hydroxy-3-oxo-3H-xanthen9-yl)-terephthalamic acid and $N$-\{5-chloro-2-[4-(4-trifluoromethylphenyl)-1,2,5-oxadiazol-3-ylcarbamoyl]-phenyl\}-2-(6-hydroxy-3oxo-3H-xanthen-9-yl)-iso phthalamic acid mixture (20). Oregon Green 488 carboxylic acid succinimide ester $(0.078 \mathrm{mmol})$ was added to a solution of amine $19(0.078 \mathrm{mmol})$ and $\mathrm{N}-\mathrm{N}$ diisopropylethylamine $(0.39 \mathrm{mmol})$ in dry $N$ - $N$-dimethylformamide $(12 \mathrm{ml})$, and the mixture was stirred for $5 \mathrm{~h}$ at room temperature (12). After the removal of dimethylformamide under vacuum, the residue was initially filtered on silica and then purified by flash column chromatography (eluent mixture: dichloromethane/ methanol, 90:10) providing the mixture 20. Yield: $23 \%$ as yellow oil. ESI-MS: calcd. for $\mathrm{C}_{37} \mathrm{H}_{20} \mathrm{ClF}_{3} \mathrm{~N}_{4} \mathrm{O}_{8} 741$, found 763 [M+Na] $]^{+}$.

\section{Antiproliferative assay on HCT-116 cell line}

Cell line culture. The human colorectal cancer cell line HCT-116 (Cell-Lab Unimore, University of Modena and Reggio Emilia, Italy) was cultured in Dulbecco's modified Eagle medium (DMEM; Euroclone, Devon, UK), supplemented with $10 \%$ heat-inactivated fetal bovine serum (Euroclone) and 1\% Pen/Strep (Euroclone). Cultures were equilibrated with humidified $5 \%$ carbon dioxide in air at $37^{\circ} \mathrm{C}$. All studies were performed in Mycoplasma-negative cells, as routinely determined with the MycoAlert Mycoplasma detection kit (Lonza, Walkersville, MD, USA) (2).

Cytotoxicity screening. The cytotoxicity of the compounds was determined by MTT assay $(13,14)$. Briefly, the cells were seeded into 96-well plates and cultured overnight. Various concentrations of the test compounds dissolved in DMSO were then added and incubated for 48 h. After incubation, $10 \% \mathrm{v} / \mathrm{v}$ of a solution of $0.5 \mathrm{mg} / \mathrm{ml}$ MTT $(3-(4,5-$ dimethylthiazol-2-yl)-2,5-diphenyl tetrazolium bromide; SigmaAldrich) was added and then incubated at $37^{\circ} \mathrm{C}$ for $3 \mathrm{~h}$. The medium was removed and $100 \mu \mathrm{DMSO}$ were added to dissolve the dark blue crystals. After incubation for $30 \mathrm{~min}$ at room temperature to ensure the dissolution of all crystals, absorbance was measured using an ELISA plate reader (TECAN, Männedorf, Switzerland) at $595 \mathrm{~nm}$ (2).

Antiproliferative assay on HeLa cell line

Cell line culture. The human cervix adenocarcinoma cell line HeLa was grown in Nutrient Mixture F-12 [HAM] (Sigma Chemical Co., St. Louis, MO, USA) supplemented with $10 \%$ heat-inactivated fetal calf serum (FCS; Invitrogen, Carlsbad, CA, USA), $100 \mathrm{U} / \mathrm{ml}$ penicillin, $100 \mu \mathrm{g} / \mathrm{ml}$ streptomycin and $0.25 \mu \mathrm{g} / \mathrm{ml}$ amphotericin B (Sigma Chemical Co.). The cells were cultured at $37^{\circ} \mathrm{C}$ in a moist atmosphere of $5 \%$ carbon dioxide in air (11).

Cytotoxicity screening. HeLa $\left(4-5 \times 10^{4}\right)$ cells were seeded into a $24-$ well cell culture plate. After incubation for $24 \mathrm{~h}$, various concentrations of the test agents were added, and the cells were further incubated in standard conditions for $48 \mathrm{~h}$. A trypan blue assay (15) was performed to determine cell viability. Cytotoxicity data were expressed as $\mathrm{GI}_{50}$ values, i.e. the concentration of the test agent inducing a $50 \%$ reduction in the cell count, compared to control cultures (11).

\section{Cellular viability of MCF-7 and MDA-MB 468 cell lines}

Cell line culture. Two breast cancer cell lines were used, namely MCF-7 (ATCC: HTB-22) and MDA-MB 468 (ATCC: HTB-132). Both cell lines were cultured in DMEM supplemented with $10 \%$ FCS and 1\% GlutaMAX (BioConcept, Allschwil, Switzerland). Cells were kept at $37^{\circ} \mathrm{C}$ in a humidified atmosphere supplemented with $5 \%$ carbon dioxide.

Cell viability. Cell viability was determined through the assessment of the metabolic activity. Briefly, MCF-7 (ATCC: HTB-22) or MDA-MB 468 (ATCC: HTB-132) cells were seeded at a density of 5,000 cells/well in 96-well plates (Eppendorf, Schönenbuch, Switzerland). Compound $\mathbf{4}$ was solubilized in DMSO at a final concentration of $15 \mathrm{mM}$ and stored at $4^{\circ} \mathrm{C}$ until further use. One day after the seeding, the cells were exposed to a medium containing a serial dilution of compound 4. After a 48-h incubation, cell viability was determined using the resazurin viability fluorometric cell viability kit (PromoCell GmbH, Heidelberg, Germany) according to the manufacturer's instruction. Fluorescence was detected using the TECAN Infinite M200Pro plate reader $(E x=530 \mathrm{~nm}, E m=590 \mathrm{~nm})$. Viability was calculated as fold of solvent control, after subtracting the fluorescence of the medium. Data were plotted using Graph Pad Prism (version 6.07, La Jolla, CA, USA); the inhibitory potency was estimated calculating the $\mathrm{GI}_{50}$ value using a nonlinear fit regression.

MeT-5A inhibition growth assay. MeT-5A (human mesothelium) cells were grown in RPMI-1640 (Sigma Chemical Co.), supplemented with $2.4 \mathrm{~g} / 1$ Hepes, $0.11 \mathrm{~g} / 1 \mathrm{Na}$-pyruvate, $2.5 \mathrm{~g} / \mathrm{l}$ 
Table I. Antiproliferative activity of compounds 1-12 against the human colorectal cancer (HCT-116) and cervix adenocarcinoma (HeLa) cell lines, evaluated after 48 hours of exposure to the compounds $(2,11)$.

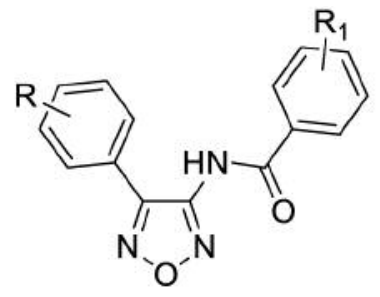

\begin{tabular}{|c|c|c|c|c|c|c|c|c|c|}
\hline Entry & $\mathbf{R}$ & $\mathbf{R}_{\mathbf{1}}$ & $\begin{array}{c}\text { HCT-116 } \\
\text { GI }_{50} \mu \mathrm{M}\end{array}$ & $\begin{array}{c}\text { HeLa } \\
\text { GI }_{50} \mu \mathrm{M}\end{array}$ & Entry & $\mathbf{R}$ & $\mathbf{R}_{1}$ & $\begin{array}{c}\text { HCT-116 } \\
\text { GI }_{50} \mu \mathrm{M}\end{array}$ & $\begin{array}{c}\text { HeLa } \\
\text { GI }_{50} \mu \mathrm{M}\end{array}$ \\
\hline 1 & $p-\mathrm{Cl}$ & $p-\mathrm{CF}_{3}$ & $1.3 \pm 0.2$ & $3.6 \pm 0.4$ & 7 & $p-\mathrm{Cl}$ & $\mathrm{H}$ & n.a. & $54.5 \pm 12.7$ \\
\hline 2 & $p-\mathrm{Cl}$ & $m-\mathrm{CF}_{3}$ & $7.4 \pm 1.15$ & $4.1 \pm 0.8$ & 8 & $m-\mathrm{Cl}$ & $p-\mathrm{CF}_{3}$ & $15.4 \pm 2.8$ & $5.7 \pm 1.1$ \\
\hline 3 & $p-\mathrm{Cl}$ & $o-\mathrm{CF}_{3}$ & n.a. & $74.5 \pm 10.2$ & 9 & $o-\mathrm{Cl}$ & $p-\mathrm{CF}_{3}$ & $56.7 \pm 3.1$ & $19.2 \pm 2.3$ \\
\hline 4 & $p-\mathrm{CF}_{3}$ & $p-\mathrm{Cl}$ & $0.95 \pm 0.02$ & $1.48 \pm 0.3$ & 10 & $p-\mathrm{Br}$ & $p-\mathrm{CF}_{3}$ & $47.7 \pm 6.3$ & $29.2 \pm 4.2$ \\
\hline 5 & $p-\mathrm{Cl}$ & $p-\mathrm{Br}$ & $85.6 \pm 16$ & $18.6 \pm 3.5$ & 11 & $p-\mathrm{CH}_{3}$ & $p-\mathrm{CF}_{3}$ & $56.5 \pm 9.1$ & $36.0 \pm 5.4$ \\
\hline 6 & $p-\mathrm{Cl}$ & $p-\mathrm{CH}_{3}$ & $47.2 \pm 5.4$ & $23.2 \pm 1.8$ & 12 & $\mathrm{H}$ & $p-\mathrm{CF}_{3}$ & n.a. & $27.0 \pm 0.4$ \\
\hline
\end{tabular}

$\mathrm{GI}_{50}$ values $(\mu \mathrm{M})$ are means $\pm \mathrm{SD}$ of at least three separate experiments; n.a.: not active $(\geq 100)$.

glucose, 2g/l Na-bicarbonate. Heat-inactivated FCS 10\%, $100 \mathrm{U} / \mathrm{ml}$ penicillin, $100 \mu \mathrm{g} / \mathrm{ml}$ streptomycin and $0.25 \mu \mathrm{g} / \mathrm{ml}$ amphotericin B (Sigma Chemical Co.) were added to the medium. The cells were cultured at $37^{\circ} \mathrm{C}$ in a moist atmosphere of $5 \%$ carbon dioxide in air. Cells $\left(3 \times 10^{4}\right)$ were seeded into a $24-$ well cell culture plate. After incubation for $24 \mathrm{~h}$, various concentrations of the test agents were added to the complete medium and the cells were further incubated for $48 \mathrm{~h}$. A trypan blue assay was performed to determine the cell viability. Cytotoxicity data were expressed as $\mathrm{GI}_{50}$ values, i.e., the concentration of the test agent inducing 50\% reduction in the number of cancer cells, compared to control cultures.

Microscope fluorescence analysis. The breast cancer cell line MCF7 (ATCC HBT-22) was used for the assessment of microtubule interaction with the fluorescent mixture 20. MCF-7 cells were cultured in supplemented DMEM on glass cover slips until the $70 \%$ confluence was reached. Then, the fluorescent mixture $\mathbf{2 0}$ was added to the cell culture at a concentration of 1,10 , and $100 \mu \mathrm{M}$ and incubated for $24 \mathrm{~h}$ at $37^{\circ} \mathrm{C}, 5 \%$ carbon dioxide in humidified atmosphere.

Fluorescence microscopy. Fluorescence microscopy was performed using an inverted fluorescent microscope Leica DM IL LED (Heerbrugg, Switzerland). Briefly, MCF-7 cells were fixed in paraformaldehyde $4 \%$ for $15 \mathrm{~min}$ at room temperature. After three washes in phosphate buffer saline (PBS) at $\mathrm{pH} 7.4$, cells were stained first with phalloidin 555 (Thermo Fischer, Zug, Switzerland) for $20 \mathrm{~min}$ and then with Hoechst 33342 (Thermo Fisher) for 10 min. All cells were co-stained with phalloidin 555 (staining F-actin of the cytoskeleton) and Hoechst 33342 (staining DNA). Three final washes were then performed before mounting the glass slides, and then fluorescent microscopy was performed. Images were taken using the software Leica suite X (LASX), and they were analyzed using the Image Processing Software.

Topoisomerase-mediated DNA relaxation assay. Supercoiled pBR322 plasmid DNA (0.25 $\mu \mathrm{g}$; Fermentas Life Sciences, Burlington, Ontario, Canada) was incubated with $1 \mathrm{U}$ topoisomerase II (human recombinant topoisomerase II $\alpha$; USB Corporation, Cleveland, $\mathrm{OH}$, USA) and the test compounds as indicated, for $60 \mathrm{~min}$ at $37^{\circ} \mathrm{C}$ in 20 $\mu \mathrm{l}$ reaction buffer. Reactions were stopped by adding $4 \mu \mathrm{l}$ stop buffer ( $5 \%$ sodium dodecyl sulfate (SDS), $0.125 \%$ bromophenol blue, and $25 \%$ glycerol), $50 \mu \mathrm{g} / \mathrm{ml}$ proteinase $\mathrm{K}$ (Sigma-Aldrich) and were further incubated for $30 \mathrm{~min}$ at $37^{\circ} \mathrm{C}$. The samples were separated by electrophoresis on a $1 \%$ agarose gel at room temperature. The gels were stained with ethidium bromide $1 \mu \mathrm{g} / \mathrm{ml}$ in TAE buffer (0.04 M Tris-acetate and 0.001 M EDTA) and transilluminated by UV light; fluorescence emission was visualized by a CCD camera, coupled to a Bio-Rad Gel Doc XR apparatus (11).

Statistical analysis. For statistical analysis, the software GraphPad Prim was used. For statistical analysis of the cell viability the One- 

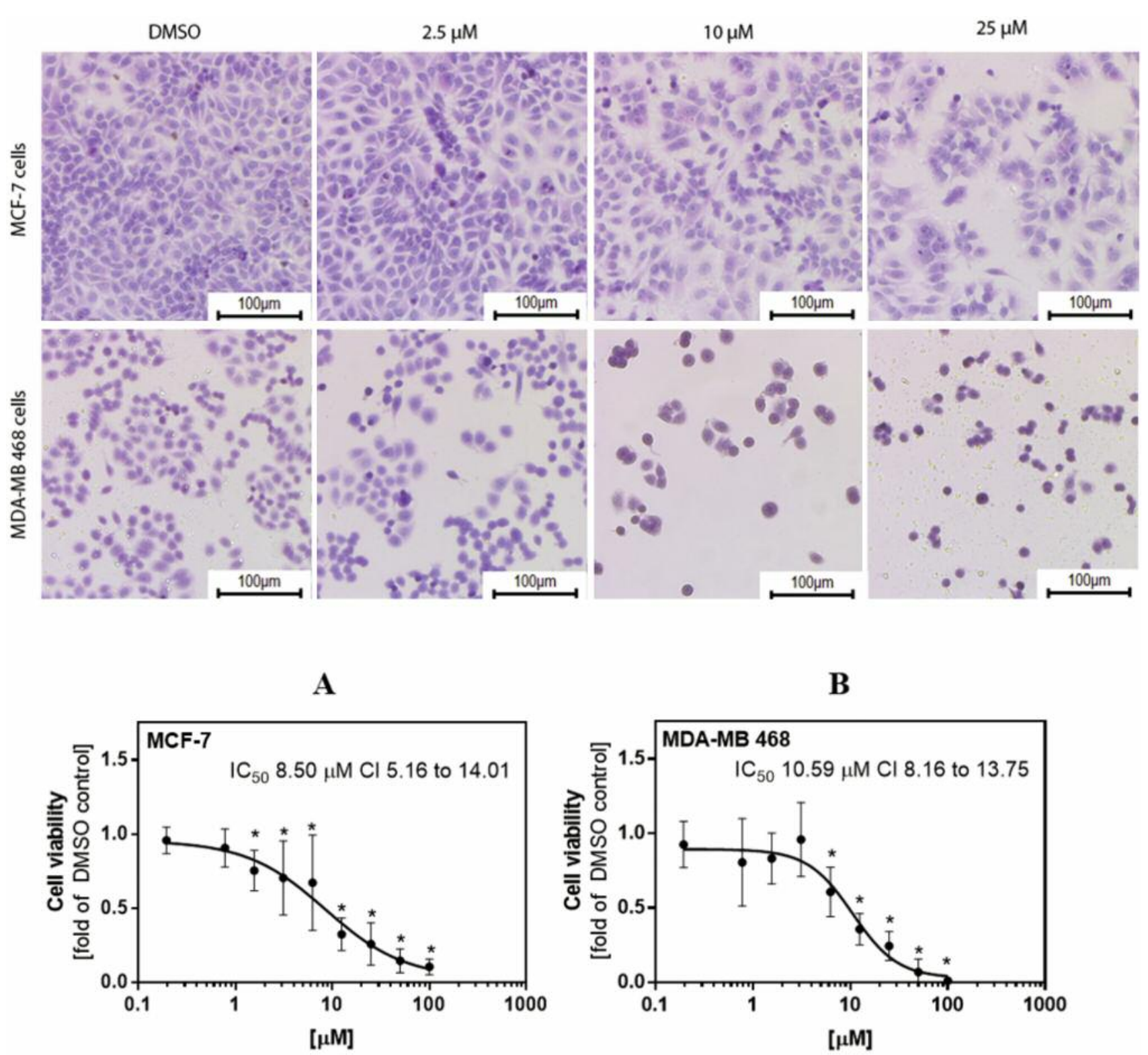

Figure 4. Effect of compound 4 on the viability of breast cancer cells (at the top); specifically, on the ER-positive MCF-7 (A) and the ER-negative $M D A-M B 468(B)$ cell lines. The viability of cells exposed to serial dilutions of compound 4 for $48 h$ was assessed by quantifying the enzymatic reduction of resazurin. The experiments $(n=4)$ were conducted in triplicates. Data are presented as mean $\pm S D$. * $p<0.05$ One-way ANOVA compared to control.

way ANOVA with Dunett's multi comparison test was used. The two-way ANOVA was applied for statistical analysis of the cell counting, while two data points comparing the $\mathrm{GI}_{50}$-values was analyzed using an unpaired $t$-test. A $p$-value $<0.05$ was considered statistically significant.

\section{Results and Discussion}

Chemistry. Our library of 1,2,5-oxadiazole derivatives, including the previously reported products $\mathbf{1 - 4}, \mathbf{7 - 9}, \mathbf{1 2}$, was integrated with the new analogues 5, 6, 10, 11, obtained following the synthetic pathway described in the literature, and depicted in Figure 2 (2). Compound 20 was afforded as a mixture of regioisomers, as described in Figure 3.

The suitable commercially available benzaldehydes were treated with hydroxylamine to give oximes $\mathbf{1 3 a - g}$, which were then converted into the corresponding chloro-oximes 14a-g in the presence of $N$-chlorosuccinimide. The chlorine atom was substituted with a cyano group by treatment with 
A

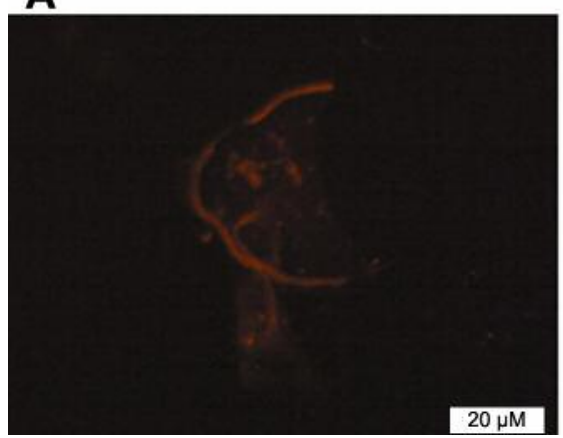

B

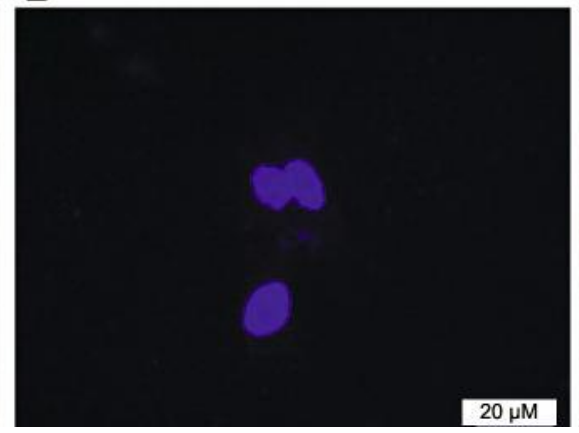

C

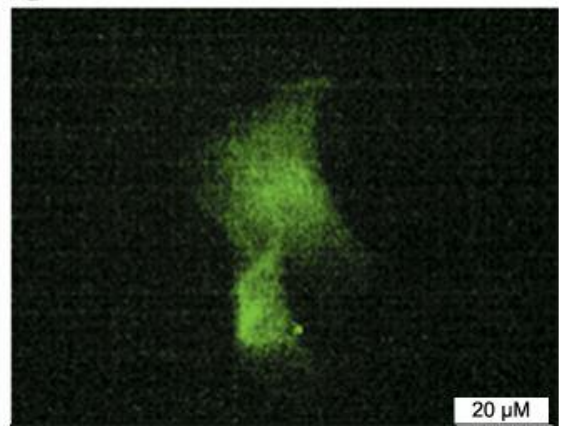

Figure 5. Images showing the presence of the fluorescent compound 20 in 488 MCF-7 breast cancer cells. Phalloidin Alexa Fluor 555 dye staining (A); Hoechst 3342 staining (B); Fluorescent mixture 20 staining (C).

potassium cyanide (15a-g). Intermediates $\mathbf{1 5 a - g}$ were reacted in the presence of hydroxylamine to afford the corresponding amino-bis-oximes (acetamidines) 16a-g that were cyclized in basic condition to the amines $\mathbf{1 7 a - g}(16)$. The latter were coupled with the suitable benzoyl chlorides in the presence of sodium hydride to afford the products 1-12 and the amide 18 (Figure 2) (2). Finally, the nitro group of intermediate 18 was reduced by treatment with tin chloride to afford the amine 19, which was coupled with Oregon

Antiproliferative activity on HCT-116 and HeLa cell lines. To complete our previous set of data (2), compounds $\mathbf{5}, \mathbf{6}$, $\mathbf{1 0}$ and $\mathbf{1 1}$ were tested on HCT-116 cell line (human colorectal cancer); then, to widen the antiproliferative profile of this class, all the derivatives were also assayed on HeLa cells (human cervix adenocarcinoma). The results are reported in Table I.

The new compounds exhibited a lower antiproliferative activity against HCT-116 cell line in comparison with the previously synthesized derivatives (11); similarly, the $\mathrm{GI}_{50}$ values on HeLa cells were generally higher with respect to the majority of those obtained for the previous candidates. Among this set, compound $\mathbf{4}$ showed the highest activity versus HeLa cell line, confirming its promising antiproliferative effect, previously observed on HCT-116 cells $\left(\mathrm{GI}_{50}=1.48 \mu \mathrm{M}\right)$. Therefore, it was also tested against the breast cancer cell lines MCF-7 and MDA-MB 468.

Cellular viability of MCF-7 and MDA-MB 468 cell lines. The effect of compound $\mathbf{4}$ on the viability of MCF7 and MDA-MB 468 cells was assessed by measuring their metabolic activity, through the resazurin fluorometric cell viability kit. The results of the test are reported in Figure 4.

The assay revealed a significant inhibition of metabolic activity upon treatment with compound $\mathbf{4}$, resulting in a reduction of resazurin to resafurin. In both cell lines,
Table II. Effect of compounds $\mathbf{1}, \mathbf{2}$ and $\mathbf{4}$ on the relaxation of supercoiled plasmid DNA by topoisomerase II (TopoII).

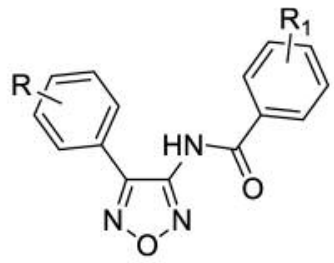

\begin{tabular}{cccc}
\hline Compound & $\mathbf{R}$ & $\mathbf{R}_{\mathbf{1}}$ & $\begin{array}{c}\text { Topo II inhibitory } \\
\text { effect }(\mathbf{1 0 0} \boldsymbol{\mu M})\end{array}$ \\
\hline $\mathbf{1}$ & $p-\mathrm{Cl}$ & $p-\mathrm{CF}_{3}$ & +++ \\
$\mathbf{4}$ & $p-\mathrm{Cl}$ & $m-\mathrm{CF}_{3}$ & +++ \\
& $p-\mathrm{CF}_{3}$ & $p-\mathrm{Cl}$ & +++ \\
\hline
\end{tabular}

+++ Complete inhibition; ++- partial inhibition, +-- weak inhibition, -- no inhibition.

compound 4 exhibited a comparable potency with an $\mathrm{GI}_{50}$ of $8.50 \mu \mathrm{M}$ in MCF-7 and an $\mathrm{GI}_{50}$ of $10.59 \mu \mathrm{M}$ in MDA-MB 468 cells (Student's $t$-test, $p>0.05$, Figure 4 ).

Antiproliferative activity on MeT-5A. Compound 4, endowed with the highest antiproliferative activity, and compound $\mathbf{1}$, as reference, were tested on MeT-5A cell line, showing $\mathrm{GI}_{50}$ values of $7.3 \mu \mathrm{M}$ and $9.3 \mu \mathrm{M}$ respectively, after $48 \mathrm{~h}$ of incubation. The compounds exhibited a lower cytotoxicity against healthy cells with respect to the tested cancer cell lines, suggesting a certain degree of specificity.

Fluorescent microscopy analysis. Following the incubation of MCF-7 breast cancer cells with the fluorescent mixture 
20, a lower viability was observed compared to the control group, in which no compound was added. Three different concentrations $(1,10$ and $100 \mu \mathrm{M})$ of the compound were used, but only the highest gave a relevant fluorescent signal (Figure 5).

The fluorescence microscopy analysis suggested an overlay between the actin and the fluorescent derivative of compound 4 (mixture 20), without showing substantial alterations of the cellular shape. Therefore, the affinity of the molecule towards the actin filament indicates a potential interaction may occur.

AlphaScreen-based assay. Several literature works have reported that oxadiazole-based derivatives can inhibit the signal transducer and activator of transcription 3 (STAT3) transcription factor, by binding to its SH2 domain $(10,17-$ 19). Therefore, the potential inhibitory activity of the most interesting compounds (1, 2 and 4) was tested at $30 \mu \mathrm{M}$ concentration by an AlphaScreen-based assay, though without positive results (data not shown).

Topoisomerase-mediated DNA relaxation assays. Some oxadiazole derivatives have also been reported to have inhibitory activity on topoisomerases $(20,21)$, so the same three compounds, endowed with the highest antiproliferative activity (1, $\mathbf{2}$ and $\mathbf{4})$, were tested against topoisomerase II (Table II).

All tested compounds showed an interesting inhibitory effect on topoisomerase II relaxation activity: the results of the assay revealed a complete enzyme inhibition at a concentration of $100 \mu \mathrm{M}$.

\section{Conclusion}

To gain new insights into the effect of phenyl substitution on the antiproliferative properties of the previously reported compound 1, a small set of oxadiazoles was synthesized and tested on different human tumor cell lines. Among the synthesized derivatives, compounds $\mathbf{2}$ and $\mathbf{4}$ showed the most interesting antiproliferative activity, highlighting that only slight modifications on compound $\mathbf{1}$, such as the shift of the $\mathrm{CF}_{3}$ group to the meta position (2) or the inversion of the position of the substituents (4), are well tolerated. Interestingly, the antiproliferative effect of $\mathbf{4}$ on non-tumorigenic MeT-5A cells appeared lower with respect to that exerted on tumor cells, suggesting a certain specificity. Further preliminary studies suggested that the antiproliferative properties of this compound could be related to the interaction with microtubules and to the ability to inhibit the relaxation activity of topoisomerase II. Therefore, these results confirm that compound $\mathbf{4}$ could be considered as a promising antiproliferative agent, endowed with a good specificity for the tested cancer cell lines.

\section{Conflicts of Interest}

The Authors declare no competing interests.

\section{Authors' Contributions}

DE and FP performed cytotoxicity assays and HE stainings of MCF7 and MDA-MB-468 cells. HEM financed the studies. DE, FP, HEM wrote the respective parts of the manuscript. LDV and ANGA performed biological assay on HeLa, MeT-5A and human topoisomerase II $\alpha$. LB supported the design of the compounds. MM, FM, AG and SV designed, synthesized and planned all the experiments and wrote the manuscript. SV financed the studies.

\section{Acknowledgements}

This research was financially supported by the University of Milan and the Italian MIUR (PRIN Research Project grant no. 20105YY2H-007, Prof. D. Barlocco). The authors would like to thank Prof. Akira Asai for the AlphaScreen-based assay on STAT3 SH2 domain, Prof. Gaetano Marverti for the HCT-116 assay and Dr. Federica Porta for her helpful support.

\section{References}

1 Cancer. Geneva, WHO, 2018. Available from: https://www.who. int/news-room/fact-sheets/detail/cancer [Accessed March 9, 2019].

2 Porta F, Gelain A, Barlocco D, Ferri N, Marchianò S, Cappello V, Basile L, Guccione S, Meneghetti F and Villa S: A field-based disparity analysis of new 1,2,5-oxadiazole derivatives endowed with antiproliferative activity. Chem Biol Drug Des 90: 820-839, 2017. PMID: 28419754. DOI: 10.1111/cbdd.13003

3 Masciocchi D, Villa S, Meneghetti F, Pedretti A, Barlocco D, Legnani L, Toma L, Kwon BM, Nakano S, Asai A and Gelain A: Biological and computational evaluation of an oxadiazole derivative (MD77) as a new lead for direct STAT3 inhibitors. Med Chem Commun 3: 592-599, 2012. DOI: 10.1039/ C2MD20018J

4 Shin DS, Masciocchi D, Gelain A, Villa S, Barlocco D, Meneghetti F, Pedretti A, Han YM, Han DC, Kwon BM, Legnani L and Toma L: Synthesis, modeling, and crystallographic study of 3,4-disubstituted-1,2,5- oxadiazoles and evaluation of their ability to decrease STAT3 activity. Med Chem Commun 1: 156-164, 2010. DOI: 10.1039/C0MD00057D.

5 Villa S, Masciocchi D, Gelain A and Meneghetti F: The influence of the substitution pattern on the molecular conformation of ureido-1,2,5-oxadiazoles, related to STAT3 inhibitors: Chemical behavior and structural investigation. Chem Biodivers 9: 1240-1253, 2012. PMID: 22782873. DOI: 10.1002/ cbdv.201100339

6 Masciocchi D, Gelain A, Porta F, Meneghetti F, Pedretti A, Celentano G, Barlocco D, Legnani L, Toma L, Kwon BM, Asai A and Villa S: Synthesis, structure-activity relationships and stereochemical investigations of new tricyclic pyridazinone derivatives as potential STAT3 inhibitors. Med Chem Commun 4: 1181-1188, 2013. DOI: 10.1039/C3MD00095H

7 Dell'Orto S, Masciocchi D, Villa S, Meneghetti F, Celentano G, Barlocco D, Colombo D, Legnani L, Toma L, Jeon YJ, Kwon 
BM, Asai A and Gelain A: Modeling, synthesis and NMR characterization of novel chimera compounds targeting STAT3. Med Chem Commun 5: 1651-1657, 2014. DOI: 10.1039/C4 MD00177J

8 Meneghetti F, Villa S, Masciocchi D, Barlocco D, Toma L, Han DC, Kwon BM, Ogo N, Asai A, Legnani L and Gelain A: Ureido-Pyridazinone Derivatives: Insights into the structural and conformational properties for STAT3 inhibition. Eur J Org Chem 2015: 4907-4912, 2015. DOI: 10.1002/ejoc.201500599

9 Gabriele E, Porta F, Facchetti G, Galli C, Gelain A, Meneghetti F, Rimoldi I, Romeo S, Villa S, Ricci C, Ferri N, Asai A, Barlocco D and Sparatore A: Synthesis of new dithiolethione and methanethiosulfonate systems endowed with pharmaceutical interest. Arkivoc 2: 235-250, 2016. DOI: $10.3998 /$ ark.5550 190.p009.805

10 Porta F, Facchetti G, Ferri N, Gelain A, Meneghetti F, Villa S, Barlocco D, Masciocchi D, Asai A, Miyoshi N, Marchianò S, Kwon BM, Jin Y, Gandin V, Marzano C and Rimoldi I: An in vivo active 1,2,5-oxadiazole $\mathrm{Pt}(\mathrm{II})$ complex: A promising anticancer agent endowed with STAT3 inhibitory properties. Eur J Med Chem 131: 196-206, 2017. PMID: 28324784. DOI: 10.1016/j.ejmech.2017.03.017

11 Gelain A, Mori M, Meneghetti F, Porta F, Basile L, Marverti G, Asai A, Hyeraci MF, Garcia-Argaezc AN, Dalla Via L, Guccione $S$ and Villa S: Exploring the biological activity of a library of 1,2,5-oxadiazole derivatives endowed with antiproliferative activity. Anticancer Res 39: 135-144, 2019. PMID: 30591450. DOI: 10.21873 /anticanres.13089

12 Cattò C, Grazioso G, Dell'Orto S, Gelain A, Villa S, Marzano V, Vitali A, Villa F, Cappitelli F and Forlani F: The response of Escherichia coli biofilm to salicylic acid. Biofouling 33: 235251, 2017. PMID: 28270055. DOI: 10.1080/08927014. 2017.1286649

13 Mosmann T: Rapid colorimetric assay for cellular growth and survival: Application to proliferation and cytotoxicity assays. J Immunol Methods 65: 55-63, 1983. PMID: 6606682. DOI: 10.1016/0022-1759(83)90303-4

14 Rimoldi I, Facchetti G, Lucchini G, Castiglioni E, Marchianò S and Ferri N: In vitro anticancer activity evaluation of new cationic platinum(II) complexes based on imidazole moiety. Bioorg Med Chem 25: 1907-1913, 2017. PMID: 28254366. DOI: $10.1016 /$ j.bmc.2017.02.010
15 Strober W. Trypan blue exclusion test of cell viability. Curr Protoc Immunol 21(1): 1-2, 2001. PMID: 18432654. DOI:10. 1002/0471142735.ima03bs21

16 Chiarelli LR, Mori M, Barlocco D, Beretta G, Gelain A, Pini E, Porcino M, Mori G, Stelitano G, Costantino L, Lapillo M, Bonanni D, Poli G, Tuccinardi T, Villa S and Meneghetti F: Discovery and development of novel salicylate synthase (MbtI) furanic inhibitors as antitubercular agents. Eur J Med Chem 155: 754-763, 2018. PMID: 29940465. DOI: 10.1016/j.ejmech.2018. 06.033

17 Gelain A, Mori M, Meneghetti F and Villa S: Signal transducer and activator of transcription protein 3 (STAT3): an update on its direct inhibitors as promising anticancer agents. Curr Med Chem, 2018. PMID: 30027840. DOI: 10.2174/09298673256661 80719122729

18 Sgrignani J, Garofalo M, Matkovic M, Merulla J, Catapano C V., Cavalli A, Sgrignani J, Garofalo M, Matkovic M, Merulla J, Catapano CV and Cavalli A: Structural biology of STAT3 and its implications for anticancer therapies development. Int J Mol Sci 19: 1591, 2018. PMID: 29843450. DOI: 10.3390/ijms 19061591

19 Matsuno K, Masuda Y, Uehara Y, Sato H, Muroya A, Takahashi O, Yokotagawa T, Furuya T, Okawara T, Otsuka M, Ogo N, Ashizawa T, Oshita C, Tai S, Ishii H, Akiyama Y and Asai A: Identification of a new series of STAT3 inhibitors by virtual screening. ACS Med Chem Lett 1: 371-375, 2010. PMID: 24900220. DOI: $10.1021 / \mathrm{ml} 1000273$

20 Feng C, Wang L, Yan Y, Liu J and Li S: Synthesis and antitumor evaluation of some 1,3,4-oxadiazole-2(3H)-thione and 1,2,4triazole-5(1H)-thione derivatives. Med Chem Res 21: 315-320, 2012. DOI: 10.1007/s00044-010-9544-6

21 Subba Rao AV, Vishnu Vardhan MV, Subba Reddy NV, Srinivasa Reddy T, Shaik SP, Bagul C and Kamal A: Synthesis and biological evaluation of imidazopyridinyl-1,3,4-oxadiazole conjugates as apoptosis inducers and topoisomerase II $\alpha$ inhibitors. Bioorg Chem 69: 7-19, 2016. PMID: 27656775. DOI: 10.1016/j.bioorg.2016.09.002

Received March 12, 2019

Revised April 29, 2019

Accepted May 2, 2019 